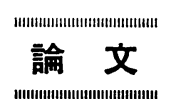

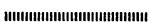

\section{クロマイトの炭素還元における律速過程}

\author{
片山博*. 徳田昌 則 ${ }^{* 2}$
}

\title{
Rate-determining Process in Carbothermic Reduction of Chromites
}

Hiroshi G. Katayama and Masanori Tokuda

Synopsis :

Synthetic $\mathrm{FeCr}_{2} \mathrm{O}_{4}$ and $\mathrm{MgCr}_{2} \mathrm{O}_{4}$ were reduced by graphite powder under various conditions of temperature and gaseous atmosphere. The kinetic data were analyzed by the use of the rate equation offered by $E$. T. Turkdogan et al. for the oxidation of carbon with gaseous $\mathrm{CO}-\mathrm{CO}_{2}$ mixture.

In the carbothermic reduction of $\mathrm{FeCr}_{2} \mathrm{O}_{4}$, the rate was clarified to be mainly controlled by the BoudouARD reaction process, which was accelerated to a great extent by the metallic and carbide phases formed. On the other hand, the reduction rate of $\mathrm{MgCr}_{2} \mathrm{O}_{4}$ appeared to be mixed-controlled by the BOUDOUARD reaction and gaseous reduction processes.

Furthermore, the rate-determining process in the carbothermic reduction of more complicated chromites and chromite ores was examined on the basis of the rate constants for the carbothermic reduction of $\mathrm{FeCr}_{2} \mathrm{O}_{4}$ and $\mathrm{Cr}_{2} \mathrm{O}_{3}$. As the result, it was clarified that the reduction rate of those chromites, especially of $\mathrm{Al}_{2} \mathrm{O}_{3}$-containing chromites is mainly controlled by the gaseous reduction process of the chromite particle.

\section{1. 緒}

\section{言}

著者らはクロム鉱石の固相域還元の基礎的研究を進め ており,これまでに各地産のクロム鉱石, それらから分 離したクロマイトおよび種々の合成クロマイトの炭素還 元実験を行い, 成分酸化物の還元過程, 被還元性に及ぼ すクロマイトの組成および脈石鉱物の影響, 還元過程に おけるクロマイト粒子の組成および構造の変化などを解 明してきた1) 7). 本報では, クロマイトの炭素還元にお ける律速過程およびそれに及ぼすクロマイトの組成の影 響を明らかにすることとした。

クロマイトの炭素還元においては, 他の金属酸化物之 同様に Boudouard 反応と CO ガス還元反応とが平行し て同時に進行するとの見解が一般的である2) 6)8) 10). そこでこの前提に立ち, 鉱石中のクロマイトの基本的ス ピネル成分である $\mathrm{FeCr}_{2} \mathrm{O}_{4}$ および $\mathrm{MgCr}_{2} \mathrm{O}_{4}$ の炭素還 元において, 本実験条件下で起こる主な反応を示すと次 のようである.

$$
\begin{aligned}
& \mathrm{C}+\mathrm{CO}_{2}=2 \mathrm{CO} \\
& \mathrm{FeCr}_{2} \mathrm{O}_{4}+\mathrm{CO}=\mathrm{Fe}+\mathrm{Cr}_{2} \mathrm{O}_{3}+\mathrm{CO}_{2} \\
& 3 \mathrm{Cr}_{2} \mathrm{O}_{3}+17 \mathrm{CO}=2 \mathrm{Cr}_{3} \mathrm{C}_{2}+13 \mathrm{CO}_{2} \ldots \\
& 7 \mathrm{Cr}_{2} \mathrm{O}_{3}+33 \mathrm{CO}=2 \mathrm{Cr}_{7} \mathrm{C}_{3}+27 \mathrm{CO}_{2} \ldots \\
& 3 \mathrm{MgCr}_{2} \mathrm{O}_{4}+17 \mathrm{CO}=2 \mathrm{Cr}_{3} \mathrm{C}_{2}+3 \mathrm{MgO}
\end{aligned}
$$

昭和 59 年 9 月 10 日受付 (Received Sep. 10, 1984)

* 室蘭工業大学工学部 工博 (Faculty of Engineering, Muroran Institute of Technology, 27-1 Mizumoto-cho Muroran 050)

*2 東北大学選鉱製鍊研究所 工博 (Research Institute of Mineral Dressing and Metallurgy, Tohoku University)

$$
\begin{gathered}
+13 \mathrm{CO}_{2} \\
7 \mathrm{MgCr}_{2} \mathrm{O}_{4}+33 \mathrm{CO}=2 \mathrm{Cr}_{7} \mathrm{C}_{3}+7 \mathrm{MgO} \\
+27 \mathrm{CO}_{2} \quad \ldots \ldots \ldots \ldots \ldots \ldots \ldots \ldots \ldots \ldots \ldots \ldots \ldots \ldots \ldots \ldots \ldots \ldots
\end{gathered}
$$

本研究では，まず $\mathrm{FeCr}_{2} \mathrm{O}_{4}$ および $\mathrm{MgCr}_{2} \mathrm{O}_{4}$ の炭素 還元速度を種々の反応ガス压 $\left(P_{\mathrm{CO}}+P_{\mathrm{CO}_{2}}\right)$ 下において 測定し， $\mathrm{CO}-\mathrm{CO}_{2}$ 混合ガスによる炭素の酸化反応速度 式を適用して速度解析した. その結果, $\mathrm{FeCr}_{2} \mathrm{O}_{4}$ の場合 は Boudouard 反応(1)の単一律速であるが, $\mathrm{MgCr}_{2} \mathrm{O}_{4}$ の場合はガス還元過程の律速寄与も無視できないことが わかつた. そこで, さらに複雑な組成の合成クロマイト およびクロム鉱石についても，既報の還元速度データお よび新たに測定したデータを同様に解析し，それらの反 応過程のいずれが主に律速するかを検討した。

なお，上記の反応過程のみならず，粉状混合物内の䊉 子間隙拉よび各粒子内の物質移動過程もある程度律速す るものと思われるが，本報ではとくに検討しなかつた。

\section{2. 試料および実験方法}

\section{$2 \cdot 1$ 試 料}

$\mathrm{FeCr}_{2} \mathrm{O}_{4}$ 抢よび $\mathrm{MgCr}_{2} \mathrm{O}_{4}$ は前報5)6) と同様に合成し たもので, 走査電顕により粒径を測定した結果, 前者は

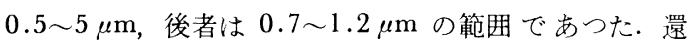
元剂は $250 \sim 325$ メッシェの黒鉛粉末で, $\mathrm{N}_{2}$ 雾囲気中 
Table 1. Size, bulk density and porosity of the tablets prepared for the present experiment.

\begin{tabular}{c|c|c|c|c}
\hline Chromite & $\begin{array}{c}\text { Diameter } \\
(\mathrm{cm})\end{array}$ & $\begin{array}{c}\text { Thickness } \\
(\mathrm{cm})\end{array}$ & $\begin{array}{c}\text { Bulk density } \\
\left(\mathrm{g} / \mathrm{cm}^{3}\right)\end{array}$ & $\begin{array}{c}\text { Porosity } \\
(-)\end{array}$ \\
\hline $\mathrm{FeCr}_{2} \mathrm{O}_{4}$ & 0.81 & 0.44 & 2.21 & 0.48 \\
\hline $\mathrm{MgCr}_{2} \mathrm{O}_{4}$ & 0.81 & 0.48 & 2.03 & 0.49 \\
\hline
\end{tabular}

約 $900^{\circ} \mathrm{C}$ にて $1 \mathrm{~h}$ 加熱後使用した。 その灰分は $0.1 \%$ 以下である。

黒鉛の配合モル比は $\mathrm{FeCr}_{2} \mathrm{O}_{4}$ の場合は $5.5, \mathrm{MgCr}_{2} \mathrm{O}_{4}$ では 4.5 とした。これらの配合比はそれぞれ $(\mathrm{Cr}, \mathrm{Fe})_{7}$ $\mathrm{C}_{3}$ および $\mathrm{Cr}_{3} \mathrm{C}_{2}$ が生成し，また生成がスは $\mathrm{CO}$ のみ であるとしたときの当量配合比（それぞれ 5.28，4.33） よりいく分過剩である. 一部の実験では, 律速過程の検 討データを得るために Boudouard 反応に対して触媒作 用11)を有する $\mathrm{K}_{2} \mathrm{CO}_{3}$ を試薬品で $1 \%$ 添加した.

混合物試料 $0.5 \mathrm{~g}$ を $1000 \mathrm{~kg} / \mathrm{cm}^{2}$ で圧縮成形してタ ブレットとし, 内径 $9 \mathrm{~mm}$, 深さ $9 \mathrm{~mm}$ の黒鉛るつぼに 入れて還元実験に供した。作製したタブレットの寸法, かさ密度および気孔率を Table 1 亿示す。

\section{$2 \cdot 2$ 実験方法}

実験装置は Fig. 1 に示すよらに, シリカスプリング 式の熱天秤に定圧排気機構をとりつけたものである. 反 応管は気密質のアルミナ製で，その内径は $28 \mathrm{~mm}$ であ る.

還元実験の手順は次のようである. すず炉温を所定温 度 $\left(1030^{\circ} \sim 1210^{\circ} \mathrm{C}\right)$ に保持したのち, 試料を反応管 (9)の上端につり下げ，ガラス管(14)を気密に接続す る. 次に油回転ポンプ（4）により反応管内を $10^{-2} \mathrm{~mm}$ $\mathrm{Hg}$ 程度まで排気し，前報5) と同様に精製した $\mathrm{CO}$ ガス をニードルバルブ（7)により徐々に導入する. 大気圧下 の還元の場合はその後直ちに後述の手順で試料を反応管 中心部に降下させ反応を開始させる，ただし，真空コッ ク (c), ニードルバルブ (7), 三方ュック (b), (a)を ガス排出口（16)に向かつて開き，還元により生成する $\mathrm{CO}$ を主体とするガスが自然に流れ出る状態にしてお $<$.

大気圧より低い全圧の場合は，コック（c）を閉じて反 応管を隔離した状態で再び排気し，同時にニードルバル ブ(6)を徐々に開いて空気を吸いこませ，水銀マノメー 夕 (2)の所定目盛に調節する. その後反応管内への空気 の侵入を防止するためニードルバルブ (5)を開いて CO ガスを約 $400 \mathrm{Ncc} / \mathrm{min}$ の流量で真空ポンプ(4)に吸い

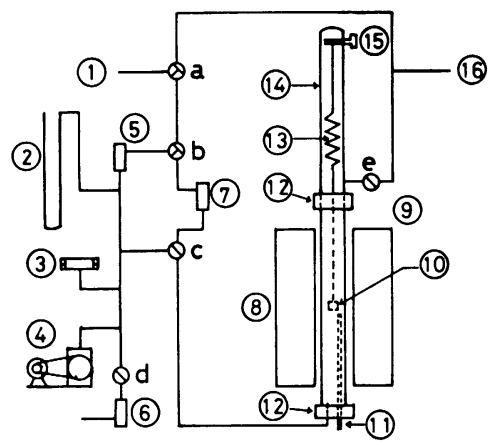

$\begin{array}{lll}\text { (1) CO gas inlet } & \text { (11) Pt-Pt.Rh T.C. } \\ \text { (2) Manometer } & \text { (12) Brass cap } \\ \text { (3) Geissler tube } & \text { (13) Silica spring } \\ \text { (4) Rotary pump } & \text { (14) Glass tube } \\ \text { (5) Needle valve } & \text { (15) Windlass } \\ \text { (6) } & \text { " } & \text { (16) Gas outlet } \\ \text { (7) } & \text { " } & \text { (a), (b) : } \\ \text { (8) Furnace } & \text { Three-way tap } \\ \text { (9) Reaction tube } & \text { (c), (d), (e) : } \\ \text { (10) Sample } & \text { Vacuum stopcock }\end{array}$

Fig. 1. Schematic diagram of experimental apparatus.

こませ，ついで真空コック（c）を真空ポンプ側に開き， 反応管内の $\mathrm{CO}$ 圧を所定圧に再調節する。なお，この 状態では $\mathrm{CO}$ ガスは反応管中を流通せず，試料の炭素 還元により生成する CO を主体とするガスは，反応管 の底部から真空コック（c)を経て真空ポンプにより排気 される。

以上の全圧調節操作の後, ウィンドラス (15)をまわし て試料を下げ, $800^{\circ} \sim 900^{\circ} \mathrm{C}$ の位置にて $3 \mathrm{~min}$ ，ついで 中心部に下げてから $2 \mathrm{~min}$ 保持後, シリカスプリング の伸びの読みとりを開始した. 所定時間経過後, 試料を 速やかにまき上げ，反応管の上端で十分冷却したのちと り出して科量した.

還元率 $(R)$ は次式により算出した.

$$
R=\left\{\frac{\left(L_{t}-L_{0}\right)\left(W_{p}-W_{e}\right)}{L_{e}-L_{0}}+\left(W_{0}-W_{p}\right)\right\} \frac{1}{W_{0} A}
$$

ここで, $L_{0}, L_{l}, L_{e}$ はカセトメータの測定開始時, $t$ 時 間後, 測定終了時の読みであり, $W_{0}, W_{p}, W_{e}$ は試料 の還元前，予熱後および測定終了後の質量である．Aは $100 \%$ 還元に相当寸る 質量減少率であるが, $\mathrm{CO}_{2}$ の生 成量が少ないので12)，CO のみが生成するとして計算で 求めた值を用いた。

\section{3. 実 験 結 果}

\section{1 クロマイト $\left(\mathrm{FeCr}_{2} \mathrm{O}_{4}\right)$ の遗元}

\section{$3 \cdot 1 \cdot 1$ 還元速度}




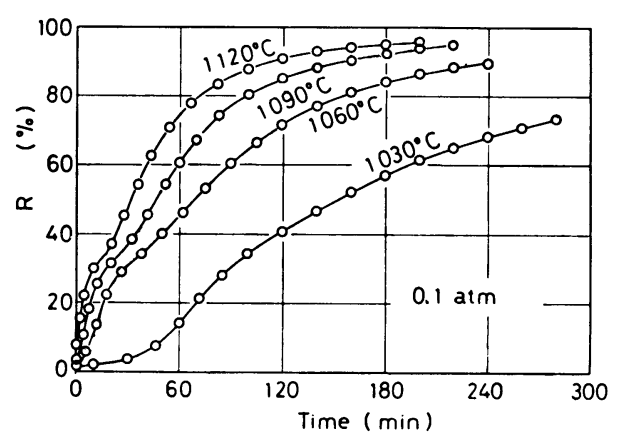

Fig. 2. Reduction curves of $\mathrm{FeCr}_{2} \mathrm{O}_{4}$ at various temperatures $\left(P_{\mathrm{CO}}+P_{\mathrm{CO}_{2}}=0.1 \mathrm{~atm}\right)$.

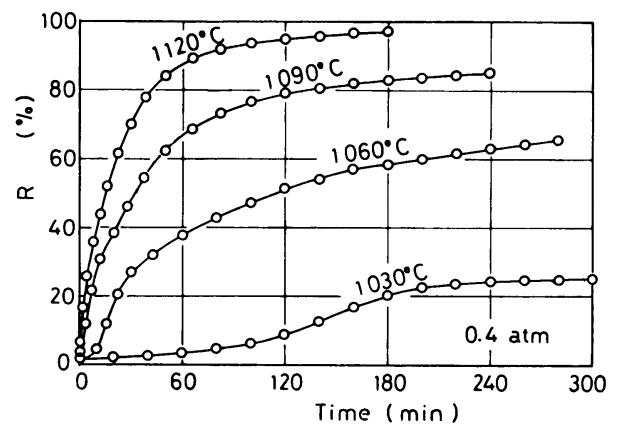

Fig. 3. Reduction curves of $\mathrm{FeCr}_{2} \mathrm{O}_{4}$ at various temperatures $\left(P_{\mathrm{CO}}+P_{\mathrm{CO}_{2}}=0.4 \mathrm{~atm}\right)$.

反応ガス圧†および温度を種々変化させて還元速度を 測定した. 還元速度曲線の数例を Fig. 2〜4 に示す.

$0.1 \mathrm{~atm}$ の反応ガス圧では $30 \%$ 前後の還元率で還元 速度は一時低下し，その後再び上昇する.この原因は $\mathrm{FeO}$ 成分の還元に続いて $\mathrm{Cr}_{2} \mathrm{O}_{3}$ 成分の還元が開始し, 生成金属相の $\mathrm{Cr}$ 濃度が上昇すると平行してその浸炭反 応も進行するので3), その結果気相の $P_{\mathrm{CO}_{2}} / P_{\mathrm{CO}}$ 比が上 昇し $\mathrm{Cr}_{2} \mathrm{O}_{3}$ 成分の還元が抑制されるためであろう.こ の段階をすぎると気相の $P_{\mathrm{CO}_{2}} / P_{\mathrm{CO}}$ 比は次第に低下し還 元速度は上昇する.このよらな浸炭反応による還元抑制 作用は反応ガス圧が低い場合にのみ現れ，0.4 atm 以上 では認められなくなる。

低温では還元初期に誘導期が現れる・これは低温ほど， また反応がス圧が高くなるほど長時間になる， $\mathrm{K}_{2} \mathrm{CO}_{3}$ を $1 \%$ 添加すると, $1030^{\circ} \mathrm{C}$ の低温還元でも誘導期は現れ ず，また還元速度は著しく上昇する。

Fig. 5 は還元率 15\% および $45 \%$ における還元速度

$\dagger$ 本実験の条件下では, 反応系の $P_{\mathrm{CO} 2} / P_{\mathrm{CO}}$ 比は反応 $(2) \sim(6)$ と反

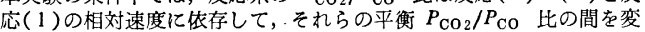
化するので, 単に $\mathrm{CO}$ 圧とせず反応ガス圧 $\left(P_{\mathrm{CO}}+P_{\mathrm{CO} 2}\right)$ と記述し た.ただしクロム系酸化物の炭素還元では $P_{\mathrm{CO}_{2}}$ は著しく低く, 最も 還元されやすい $\mathrm{FeCr}_{2} \mathrm{O}_{4}$ の $\mathrm{FeO}$ 成分の場合でも $0.01 \mathrm{~atm}$ 以下で ある.

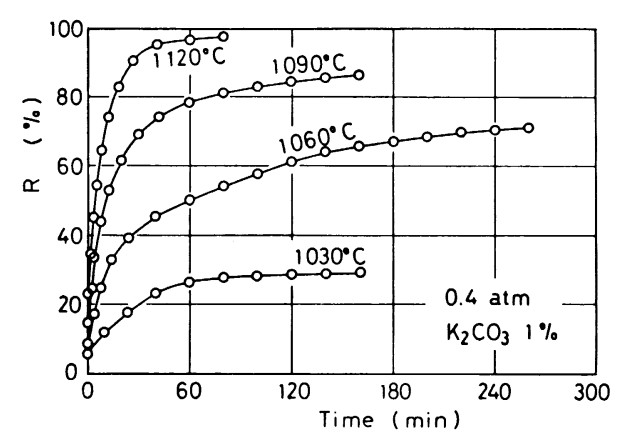

Fig. 4. Reduction curves of $\mathrm{FeCr}_{2} \mathrm{O}_{4}$ at various temperatures $\left(P_{\mathrm{CO}}+P_{\mathrm{CO}_{2}}=0.1 \mathrm{~atm}, \quad 1 \% \quad \mathrm{~K}_{2} \mathrm{CO}_{3}\right.$ addition).

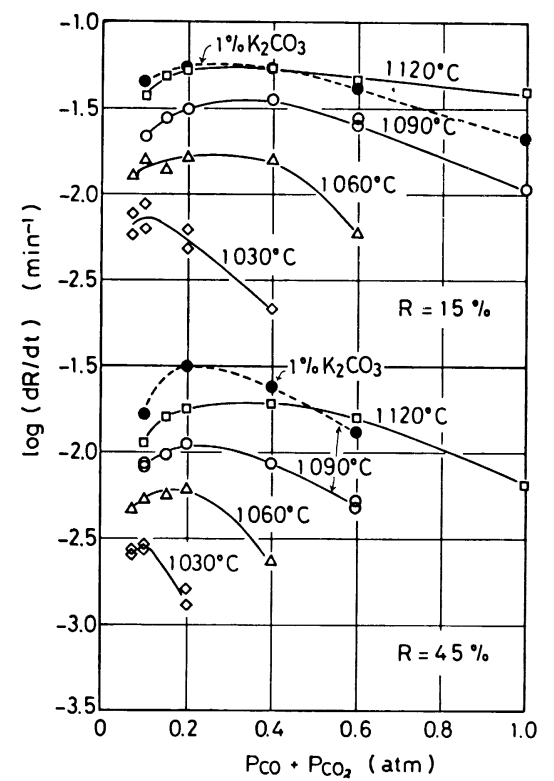

Fig. 5. Effect of the total pressure $\left(P_{\mathrm{CO}}+\mathrm{P}_{\mathrm{CO}_{2}}\right)$ of reacting gases on the reduction rate $(d R / d t)$ of $\mathrm{FeCr}_{2} \mathrm{O}_{4}$.

$(d R / d t)$ と反応ガス圧の関係を示す. 前者は $\mathrm{FeO}$ 成分, 後者は $\mathrm{Cr}_{2} \mathrm{O}_{3}$ 成分の還元速度に相当する ${ }^{3 / 5) 6)}$. $\mathrm{FeO}$ 成 分の還元速度は $1060^{\circ} \mathrm{C}$ 以上では $0.2 \sim 0.4 \mathrm{~atm}$ におい て最大となるが, $1030^{\circ} \mathrm{C}$ では約 $0.1 \mathrm{~atm}$ で最大とな る. $\mathrm{Cr}_{2} \mathrm{O}_{3}$ 成分の還元速度も同様の反応がス圧依存性を 示すが, $\mathrm{FeO}$ 成分の場合よりいく分低圧側で最大值を とる. $\mathrm{K}_{2} \mathrm{CO}_{3}$ は各反応ガス圧において還元速度を上昇 させ， とくに $\mathrm{Cr}_{2} \mathrm{O}_{3}$ 成分の還元促進作用が大きい.し かし Fig. 3 と Fig. 4 の比較から, 各温度における到 達還元率にはほとんど影響しないことがわかる。

$3 \cdot 1 \cdot 2$ 還元の進行に伴ら生成相の変化

$1090^{\circ} \mathrm{C}$ において種々の段階まで還元した試料をX線 


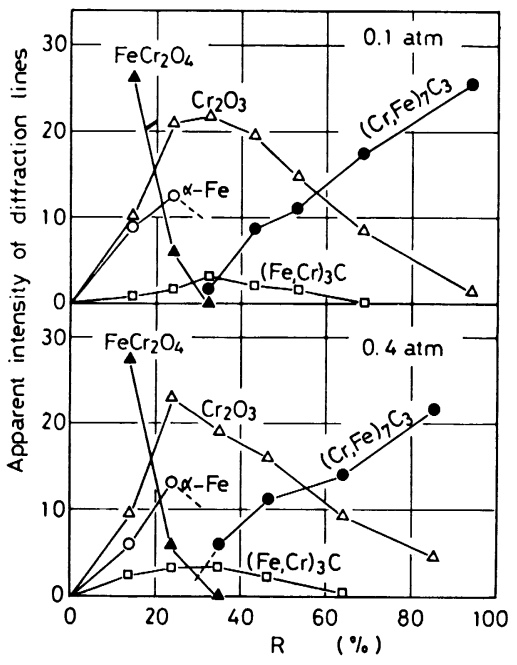

Fig. 6. X-ray analysis of $\mathrm{FeCr}_{2} \mathrm{O}_{4}$ reduced to various stages at $1090^{\circ} \mathrm{C}$.

回折し生成相を同定した.Fig. 6 は反応がス圧 0.1 お よび $0.4 \mathrm{~atm}$ の場合について各生成相の最強の回折ピ 一ク高さ（記録紙の目盛単位）と還元率の関係を示す。

$\mathrm{FeCr}_{2} \mathrm{O}_{4}$ 相の回折ピークは還元の進行とともに急速 に低下し，還元率が $30 \%$ をこえると消失する. 一方 $\mathrm{Cr}_{2} \mathrm{O}_{3}$ および金属鉄は初め增加し，25３0\% の還元 率で最大値に達したのち減少する。 $(\mathrm{Cr}, \mathrm{Fe})_{7} \mathrm{C}_{3}$ 相は $\mathrm{FeCr}_{2} \mathrm{O}_{4}$ 相が消失し, 遊離した $\mathrm{Cr}_{2} \mathrm{O}_{3}$ が還元されはじ めると生成し，次第に増えていく．七メンタイト相は一 般に少ないが，30\% 前後の還元率でいく分多く生成す る。

以上より，本実験条件下においても $\mathrm{FeCr}_{2} \mathrm{O}_{4}$ は $\mathrm{FeO}$ 成分，ついで $\mathrm{Cr}_{2} \mathrm{O}_{3}$ 成分の 2 段階に還元され， $\mathrm{FeO}$ 成 分の還元段階では $\mathrm{Cr}_{2} \mathrm{O}_{3}$ 成分の還元が ほとんど起こら ないこと3)5)6)が確認された。

\section{2 ピクロクロマイト $\left(\mathrm{MgCr}_{2} \mathrm{O}_{4}\right)$ の還元}

\section{$3 \cdot 2 \cdot 1$ 還元速度}

Fig. 7 は $1180^{\circ} \mathrm{C}$ の各反応ガス圧における還元速度 曲線を示す. $\mathrm{FeCr}_{2} \mathrm{O}_{4}$ の場合と同様に反応初期に誘導 期が現れるが, 還元温度が高いため比較的短時間である。

誘導期をすぎると還元反応は速やかに進行し，還元率 $30 \%$ 付近で最大の還元速度に達する. Fig. 8 はその 還元速度と反応ガス圧の関係を示す， $1180^{\circ} \mathrm{C}$ および $1210^{\circ} \mathrm{C}$ の還元速度はそれぞれ 0.1 および $0.2 \mathrm{~atm}$ 前 後の反応ガス圧において最大となり，それらより高圧に なつても低圧になつても低下する。

\section{$3 \cdot 2 \cdot 2$ 各種炭化物の生成条件}

Fig. 9 は約 $50 \%$ まで還元した試料のX線回折結果

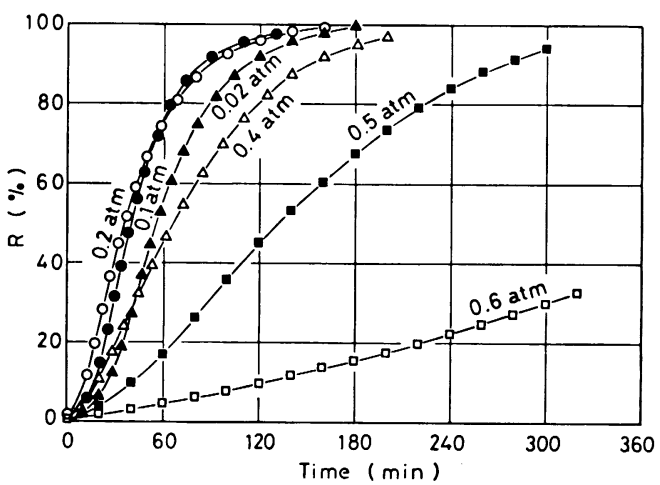

Fig. 7. Reduction curves of $\mathrm{MgCr}_{2} \mathrm{O}_{4}$ at $1180^{\circ} \mathrm{C}$ under the various pressures of reacting gases.

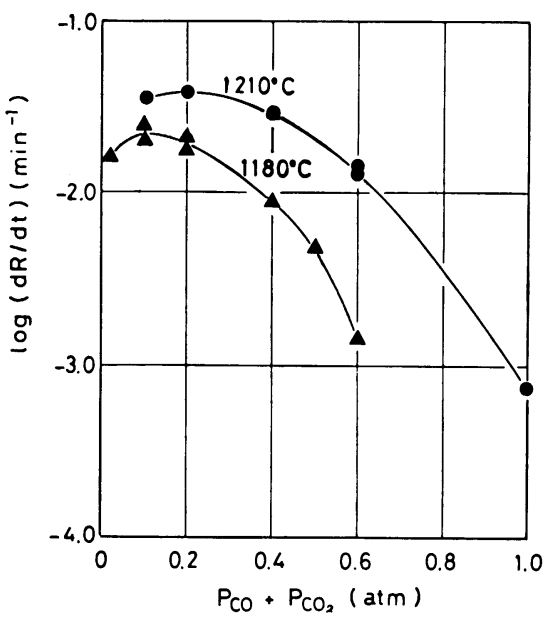

Fig. 8. Effect of the total pressure $\left(P_{\mathrm{CO}}+P_{\mathrm{CO}_{2}}\right)$ of reacting gases on the reduction rate $(d R / d t)$ of $\mathrm{MgCr}_{2} \mathrm{O}_{4}$.

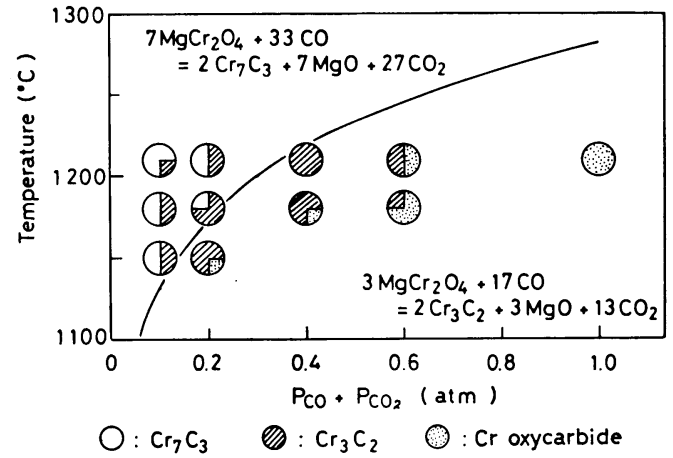

Fig. 9. Change in reduction product with the total pressure of reacting gases and temperature.

に基づいて，種々の還元条件下における $\mathrm{Cr}_{3} \mathrm{C}_{2}, \mathrm{Cr}_{7} \mathrm{C}_{3}$ およびオキシ炭化物相5)6) の生成割合をごく大まかに示 
したものである. 図中の曲線は $\mathrm{Cr}_{3} \mathrm{C}_{2}$ が生成する還元 反応 (5)の平衡 $P_{\mathrm{CO}_{2}} / P_{\mathrm{CO}}$ 比と $\mathrm{Cr}_{7} \mathrm{C}_{3}$ が生成する還元 反応 $(6)$ のそれとが同一になるときの温度と反応ガス圧 の関係を示す.すなわち, 気相が $\mathrm{MgCr}_{2} \mathrm{O}_{4}$ と平衡して いる場合には，その曲線上り下方は $\mathrm{Cr}_{3} \mathrm{C}_{2}$ の生成領域, 上方は $\mathrm{Cr}_{7} \mathrm{C}_{3}$ の生成領域である.

生成炭化物の同定結果は上述の曲線とほぼ対応してお り, したがつて気相の $P_{\mathrm{CO}_{2}} / P_{\mathrm{CO}}$ 比は反応の進行中 は $\mathrm{CO}$ 還元反応の平衡分圧比に近いとい方る. しかし $\mathrm{Cr}_{7} \mathrm{C}_{3}$ の生成領域においても $\mathrm{Cr}_{3} \mathrm{C}_{2}$ が一部生成してい るので， ある部分の気相の $P_{\mathrm{CO}_{2}} / P_{\mathrm{CO}}$ 比は $\mathrm{Cr}_{7} \mathrm{C}_{3}$ が生 成する還元反応の平衡分圧比より Boudouard 反応の平 衡分圧比寄りにいく分低下し， $\mathrm{Cr}_{3} \mathrm{C}_{2}$ が生成寸る還元反 応の平衡分圧比を下まわつたことを示す。

オキシ炭化物相は $\mathrm{Cr}_{3} \mathrm{C}_{2}$ の生成領域の低温, 高圧側 において生成しやすい，また反応初期にいつたん生成し ても反応後期になると次第に $\mathrm{Cr}_{3} \mathrm{C}_{2}$ に変化していく このことからオキシ炭化物相は安定存在域が非常に狭い か，あるいは還元途上に現机る準安定相であろう。

\section{4. 速度解析および考察}

誘導期を経過後の律速過程は, ク口ム系酸化物の場合 でも $\mathrm{CO}$ 還元反応ではなく，Boudouard 反応であると の見解が多(13) 15). 著者の一人も同じ前提に立ち, $\mathrm{Cr}_{2} \mathrm{O}_{3}$ および $\mathrm{MgCr}_{2} \mathrm{O}_{4}$ の $\mathrm{Ar}$ 雾囲気中の 炭素還元デ 一タを速度解析してきたが，Ar 雾囲気中では反応ガス 圧が不定のため戦密な速度解析ができなかつだ12).

$\mathrm{CO}-\mathrm{CO}_{2}$ 混合ガスによる炭素の酸化速度式はいくつ か提出されているが，本研究ではそれらのらち小林ら ${ }^{16)}$ が推奨した TURKDOGAN らの式( 8$)^{17)}$ を用いた.

$$
-\frac{1}{m} \frac{d m}{d t}=\frac{k_{1}\left[P_{\mathrm{CO}_{2}}-\left(P_{\mathrm{CO}_{2}}\right)_{B}\right]}{1+k_{2} P_{\mathrm{CO}}}
$$

ここで, $m:$ 炭素の質量 $(\mathrm{g}), k_{1}$ : 反応速度定数 $\left(\mathrm{atm}^{-1} \cdot \mathrm{s}^{-1}\right), P_{\mathrm{CO}}, P_{\mathrm{CO}_{2}}$ : 各ガスの分圧 $(\mathrm{atm})$, $\left(P_{\mathrm{CO}_{2}}\right)_{B}$ : Boudouard 反応の平衡 $\mathrm{CO}_{2}$ 圧 $(\mathrm{atm}), k_{2}$ : 吸着平衡定数 $\left(\mathrm{atm}^{-1}\right)$.

一定の温度および反応ガス圧では $P_{\mathrm{CO}_{2}}$ および $P_{\mathrm{CO}}$ は一定と仮定し, $t=0$ において $m=m_{0}, t=t$ と打いて $m=m_{t}$ として上式を積分し, $f=\left(m_{0}-m_{t}\right) / m_{0}$ とおいて 整理すると次式となる.

$$
-\ln (1-f)=\alpha t
$$

ただし，

$$
\alpha=\frac{k_{1}\left[P_{\mathrm{CO}_{2}}-\left(P_{\mathrm{CO}_{2}}\right)_{B}\right]}{1+k_{2} P_{\mathrm{CO}}}
$$

$\mathrm{FeCr}_{2} \mathrm{O}_{4}$ の $\mathrm{FeO}$ 成分の還元段階について, $\ln (1-f)$

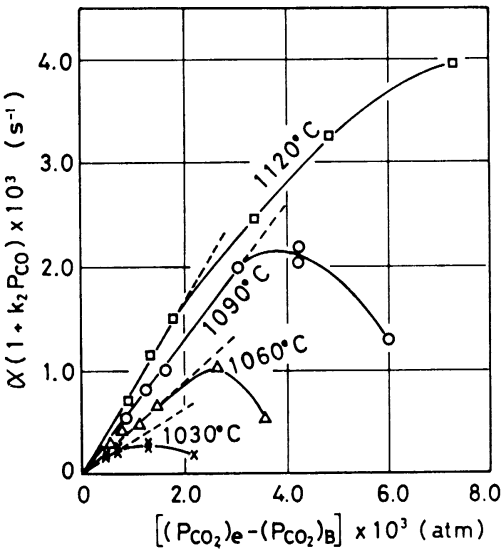

Fig. 10. Relation between $\alpha\left(1+k_{2} P_{\mathrm{CO}}\right)$ and $\left[\left(P_{\mathrm{CO}_{2}}\right)_{e}-\left(P_{\mathrm{CO}_{2}}\right)_{B}\right]$ for the reduction stage of $\mathrm{FeO}$ component of $\mathrm{FeCr}_{2} \mathrm{O}_{4}$.

対 $t$ のプロットの直線部分から $\alpha$ を求め, (10)式にし たがつて $\alpha\left(1+k_{2} P_{\mathrm{CO}}\right)$ 対 $\left[P_{\mathrm{CO}_{2}}-\left(P_{\mathrm{CO}_{2}}\right)_{B}\right]$ をプロット した結果を Fig. 10 と示す。なお， $P_{\mathrm{CO}_{2}}$ は前提により $\mathrm{FeCr}_{2} \mathrm{O}_{4}$ の $\mathrm{FeO}$ 成分の還元反応 (2) の平衡 $\mathrm{CO}_{2}$ 圧 $\left(P_{\mathrm{CO}_{2}}\right)_{e}$ を用い，また $k_{2}$ は TURKDOGAN らの報告值 ${ }^{17)}$ を用いた。 $\left[\left(P_{\mathrm{CO}_{2}}\right)_{e}-\left(P_{\mathrm{CO}_{2}}\right)_{B}\right]$ が小さい範用，すなお ち反応ガス圧が低い場合は良好な直線関係が成立するの で，その勾配から $k_{1}$ を求めることができる。これに対 して, $\mathrm{MgCr}_{2} \mathrm{O}_{4}$ の場合は (10)式のプロットが直線にな らず，Boudouard 反応の単一律速の条件を見出せなか つた。

一方， $\mathrm{FeCr}_{2} \mathrm{O}_{4}$ の $\mathrm{Cr}_{2} \mathrm{O}_{3}$ 成分の還元段階では，反応 の進行之ともに生成金属相の $\mathrm{Cr}$ 濃度が次第に上昇し, それにともなつて $\left(P_{\mathrm{CO}_{2}}\right)_{e}$ が徐々に低下寸るので $(9)$ 式は適用できない，そこで次の微分形の速度式を用い， その速度解析プロットを Fig. 11 に示した.

$$
\frac{d f}{d t}=\frac{k_{1}\left[\left(P_{\mathrm{CO}_{2}}\right)_{e}-\left(P_{\mathrm{CO}_{2}}\right)_{B}\right]}{1+k_{2} P_{\mathrm{CO}}}
$$

な打 $d f / d t$ は還元率 $45 \%(f=0.43)$ において求め, $\left(P_{\mathrm{CO}_{2}}\right)_{e}$ は前報5)6) で推定した生成炭化物相中の $\mathrm{Cr}_{7} \mathrm{C}_{3}$ の活量值 $(0.15)$ を用いて算出した.

以上の上らにして求めた $k_{1}$ の温度依存性を Fig. 12 に示す。同戝には $\mathrm{Cr}_{2} \mathrm{O}_{3}$ の炭素還元データ18) を同様に 解析して求めた $k_{1}$ 値, 種々の金属酸化物の炭素還元に おける $k_{1}$ の文献值 ${ }^{19)}$ 21) 拈よび種々の炭素の $\mathrm{CO}-\mathrm{CO}_{2}$ 混合ガスによる酸化反応の $k_{1}$ の文献值 ${ }^{16) 17)}$ も比較のた め図示した.

本研究の $k_{1}$ 值は $\mathrm{KoHL} 5^{1992)}$ が $\mathrm{FeO}, \mathrm{NiO}, \mathrm{CoO}$ の黒鉛粉末による還元において求めた $k_{1}$ 值と近似する. 


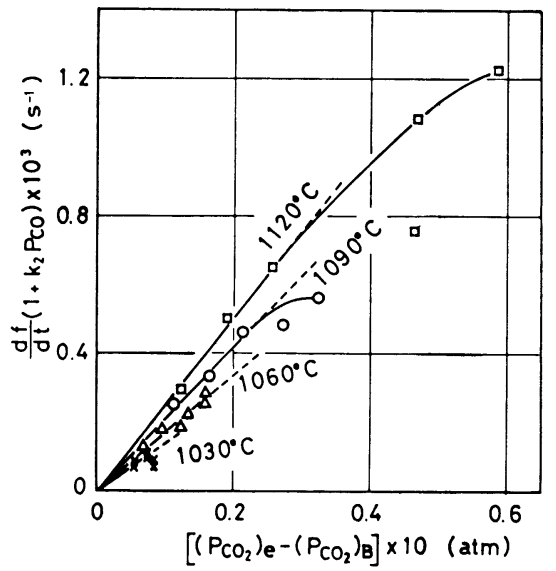

Fig. 11. Relation between $d f / d t\left(1+k_{2} P_{\mathrm{CO}}\right)$ and $\left[\left(P_{\mathrm{CO}_{2}}\right)_{e}-\left(P_{\mathrm{CO}_{2}}\right)_{B}\right]$ for the reduction stage of $\mathrm{Cr}_{2} \mathrm{O}_{3}$ component of $\mathrm{FeCr}_{2} \mathrm{O}_{4}$.

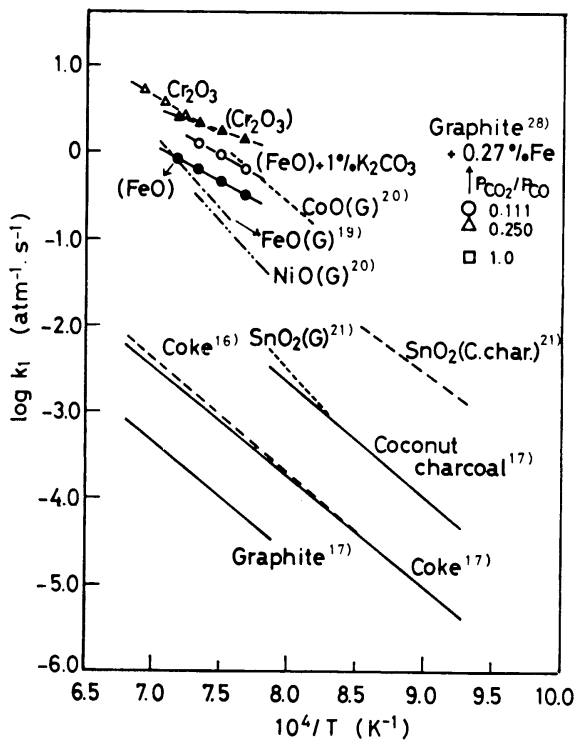

$(\mathrm{FeO})$ and $\left(\mathrm{Cr}_{2} \mathrm{O}_{3}\right)$ indicate $\mathrm{FeO}$ and $\mathrm{Cr}_{2} \mathrm{O}_{3}$ components of $\mathrm{FeCr}_{2} \mathrm{O}_{4}$, respectively.

Fig. 12. Temperature dependence of rate constants $\left(k_{1}\right)$.

しかし本研究では $\mathrm{FeCr}_{2} \mathrm{O}_{4}$ の $\mathrm{Cr}_{2} \mathrm{O}_{3}$ 成分の還元段階を 除外すれば， $40 \sim 45 \mathrm{kcal} / \mathrm{mol}$ の比較的低い活性化エネ ルギー值 $(E)$ が得られたのに対して，従来の金属酸化物 の炭素還元研究では, 同様に Boudouard 反応の単一律 速としながらも $72 \mathrm{kcal} / \mathrm{mol}$ 前後の比較的高い $E$ 值を 報告している4)12)19) 26). この原因としては，他の研 究では不活性雲囲気中の還元のため反応がス圧の温度 による変化 ${ }^{4) 12)}$ および反応の推進力である $\left[\left(P_{\mathrm{CO}_{2}}\right)_{e}-\right.$ $\left.\left(P_{\mathrm{CO}_{2}}\right)_{B}\right]$ の温度依存性を補正していないことがあげら
れる。

$\mathrm{FeCr}_{2} \mathrm{O}_{4}$ の $\mathrm{Cr}_{2} \mathrm{O}_{3}$ 成分の還元段階の $k_{1}$ 恃純粋な $\mathrm{Cr}_{2} \mathrm{O}_{3}$ の炭素還元の $k_{1}$ と近似するが，その $E$ は 24.5 $\mathrm{kcal} / \mathrm{mol}$ とかなり低い。このことから $\mathrm{Cr}_{2} \mathrm{O}_{3}$ 成分の還 元段階では生成する $\mathrm{Cr}$ 炭化物がすでに生成している金 属相中へ固溶する過程も還元速度に影響するものと考兄 られる。

Fig. 12 に打いて，金属酸化物の炭素還元から求めた $k_{1}$ は, 炭素単味の酸化反応の $k_{1}$ より同一炭種で比較し て常に大きい. 本研究の $k_{1}$ についてみれば黒鉛単味の それより約 $10^{4}$ 大き?，しか子温度依存性がかなり小さ い.この原因は還元時生成する金属および炭化物相が Boudouard 反応に対して触媒作用を有するためである ${ }^{19)}$ 〜2126)27). 本た， $\mathrm{K}_{2} \mathrm{CO}_{3} を 1 \%$ 添加した場合は無添加 より $k_{1}$ が増大し, その Boudouard 反応に対する触媒 作用 ${ }^{11)}$ が金属相のそれにある程度上積みされる.この結 果は金属相の著しい触媒作用を受けても，なお Boudouard 反応過程が主に律速することを示す.

DARKEN ら ${ }^{28)}$ は $0.27 \% \mathrm{Fe}$ を付着させた黒鉛粒子の $\mathrm{CO}-\mathrm{CO}_{2}$ 混合ガスによる酸化速度を測定し，金属鉄の 著しい触媒作用を検証している. 彼らの $800^{\circ} \mathrm{C}$ の酸化 速度データから求めた $k_{1}$ も Fig. 12 に示してあるが， それらは温度依存性を考慮すると本研究の $k_{1}$ よりさし ろ大さい。さらに注目される点は, $\mathrm{CO}-\mathrm{CO}_{2}$ 混合ガス の $P_{\mathrm{CO}_{2}} / P_{\mathrm{CO}}$ 比が高い汇ど $k_{1}$ が小さくなり, 金属鉄の 触媒作用の減少を示すことである.このことから類推し て, 反応がス圧が高くなると Fig. 10 および 11 に示さ れるように $k_{1}$ が低下するのは, Boudouard 反応の平衡 $P_{\mathrm{CO}_{2}} / P_{\mathrm{CO}}$ 比と $\mathrm{CO}$ 還元反応のそれとの相対比が上昇す るので, 生成金属および炭化物相の触媒作用が減ずるた めと考兄られる。しし，それだけでは高圧側に拈ける $k_{1}$ の著しい低下を説明できず，今後の検討課題である.

\section{5. 各種クロマイトの炭素還元における 律速過程}

$\mathrm{MgCr}_{2} \mathrm{O}_{4}$ の場合は前述のように Boudouard 反応の 単一律速として速度解析をすることができなかつた。こ れは生成炭化物種の同定結果から推定されたように，気 相の $P_{\mathrm{CO}_{2}} / P_{\mathrm{CO}}$ 比が還元平衡分圧比より Boudouard 反 応の平衡分圧比寄りにずれているためであり, したがつ て Boudouard 反応と CO 還元反応の混合律速と考え られる。

このよらにクロマイトの種類によつて炭素還元の 律速過程が相違することから, さらに $\left(\mathrm{Fe}_{\mathbf{0} .5} \mathrm{Mg}_{\mathbf{0 . 5}}\right)$ $\mathrm{Cr}_{2} \mathrm{O}_{4}(\mathrm{Sp} \mathrm{3}),\left(\mathrm{Fe}_{0.5} \mathrm{Mg}_{0.5}\right)\left(\mathrm{Cr}_{0.8} \mathrm{Al}_{0.2}\right)_{2} \mathrm{O}_{4}(\mathrm{Sp} 4), \mathrm{Mg}$ 
Table 2. Apparent rate constants for the Boudouard reaction with the carbothermic reduction of synthetic chromites and chromite ores.

\begin{tabular}{l|c|cc}
\hline \multirow{2}{*}{ Sample } & Reduced component & \multicolumn{2}{|c}{$k_{1}\left(\mathrm{~atm}^{-1} \cdot \mathrm{s}^{-1}\right)$} \\
\cline { 3 - 4 } & & $1150^{\circ} \mathrm{C}$ & $1200^{\circ} \mathrm{C}$ \\
\hline $\mathrm{Cr}_{2} \mathrm{O}_{3}+\mathrm{G}$ & & 4.2 & 7.3 \\
\hline \multirow{2}{*}{$\mathrm{Sp} \mathrm{1+G}$} & $\mathrm{FeO}$ & 1.2 & 1.9 \\
& & $5.8^{*}$ & $9.2^{*}$ \\
\cline { 2 - 4 } & $\mathrm{Cr}_{2} \mathrm{O}_{3}$ & 3.1 & 4.1 \\
\hline $\mathrm{Sp} \mathrm{2+G}$ & $\mathrm{MgCr}_{2} \mathrm{O}_{4}$ & $15.4^{*}$ & $20.6^{*}$ \\
\hline Sp 3+G & $\mathrm{FeCr}_{2} \mathrm{O}_{4}$ & - & 4.9 \\
\hline Sp 4+ G & $\mathrm{FeCr}_{2} \mathrm{O}_{4}$ & 1.6 & - \\
\hline Sp 5+ G & $\mathrm{MgCr}_{2} \mathrm{O}_{4}$ & - & $0.22^{* *}$ \\
\hline Pellet N(C) & $\mathrm{FeCr}_{2} \mathrm{O}_{4}$ & - & 0.51 \\
\hline Russ. ore+ C & $\mathrm{FeCr}_{2} \mathrm{O}_{4}$ & - & 0.53 \\
\hline
\end{tabular}

* $k_{1}$ value estimated for coke. ${ }^{* *} k_{1}$ value at $1260^{\circ} \mathrm{C}$

G: Graphite, C: Coke, $\mathrm{Sp} 1$ : $\mathrm{FeCr}_{2} \mathrm{O}_{4}, \mathrm{Sp}_{2}: \mathrm{MgCr}_{2} \mathrm{O}_{4}$, Sp 3: $\left(\mathrm{Fe}_{0.5} \mathrm{Mg}_{0.5}\right) \mathrm{Cr}_{2} \mathrm{O}_{4}$, Sp 4: $\left(\mathrm{Fe}_{0.5} \mathrm{Mg}_{0.5}\right)\left(\mathrm{Cr}_{0.8} \mathrm{Al}_{0.2}\right)_{2} \mathrm{O}_{4}$, Sp 5: $\mathrm{Mg}\left(\mathrm{Cr}_{0.6} \mathrm{Al}_{0.4}\right)_{2} \mathrm{O}_{4}$.

$\left(\mathrm{Cr}_{0.6} \mathrm{Al}_{0.4}\right)_{2} \mathrm{O}_{4}(\mathrm{Sp} 5)$ 等の合成クロマイト，炭材内装 クロム鉱ペレット $(\mathrm{N})$ およびソ連産クロム鉱石について も律速過程を検討した．検討方法は Boudouard 反応の 単一律速を仮定して (11) 式により見かけの $k_{1}$ を求め, その值を $\mathrm{FeCr}_{2} \mathrm{O}_{4}$ (Sp 1) および純 $\mathrm{Cr}_{2} \mathrm{O}_{3}$ の炭素還元 の $k_{1}$ と比較し, Boudouard 反応と $\mathrm{CO}$ 還元過程 ${ }^{\dagger 2}$ の 相対的抵抗を判定するものである. 上記試料の炭素還元 速度データは既報5)6)29) 31)のとおりであるが，合成ク口 マイトについては還元条件を近似させるため $\mathrm{N}_{2}-35 \%$ CO 雲囲気中で新たに測定した.

Table 2 は $1150^{\circ}$ および $1200^{\circ} \mathrm{C}$ (Sp 5 は 1260 $\left.{ }^{\circ} \mathrm{C}\right)$ に打名試料についての見かけの $k_{1}$ を示す。な お Sp 1 の場合は鉱石試料との比較のため還元剤として コークスを用いた場合の $k_{1}$ を見積もつて示したや3.

$\mathrm{MgCr}_{2} \mathrm{O}_{4}$ (Sp 2) の $k_{1}$ は $\mathrm{Sp} 1$ の $\mathrm{Cr}_{2} \mathrm{O}_{3}$ 成分の還 元段階の $k_{1}$ とおよそ同じであるが，純 $\mathrm{Cr}_{2} \mathrm{O}_{3}$ の $k_{1}$ よ りはかなり小さい. $\mathrm{Sp} 1$ の $\mathrm{Cr}_{2} \mathrm{O}_{3}$ 成分の還元段階では 前述のように生成 $\mathrm{Cr}$ 炭化物の金属相中への溶解過程も 還元速度に影響するので, $\mathrm{Sp} 2$ の $k_{1}$ は純 $\mathrm{Cr}_{2} \mathrm{O}_{3}$ の $k_{1}$ と比較するのが妥当であり，したがつてすでに推定した ように Boudouard 反応と CO 還元過程の混合律速と見 なされる.

$\dagger^{2}$ クロマイト粒子内の物質移動過程も含む。

$\dagger^{3} \quad$ Fig. 12 に示されるように, コークスの $k_{1}$ は黒鉛のそれより10倍 近く大きいので, 炭素還元においても少なくとも5 倍程度は大きい と見積もつた.

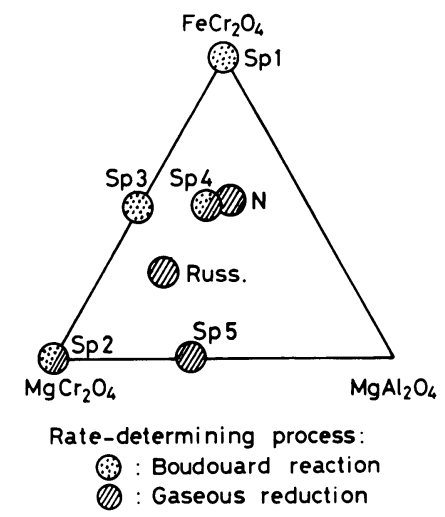

Fig. 13. Rate-determining process in the carbothermic reduction of synthetic chromites and chromite ores.

$\mathrm{Sp} 3$ および Sp 4 の $\mathrm{FeCr}_{2} \mathrm{O}_{4}$ 成分の還元段階では, $\mathrm{FeO}, \mathrm{Cr}_{2} \mathrm{O}_{3}$ 両成分がほぼ同時に還元される ${ }^{5 / 6)}$. Sp 3 の場合は $\mathrm{Sp} 1$ の $\mathrm{Cr}_{2} \mathrm{O}_{3}$ 成分および純 $\mathrm{Cr}_{2} \mathrm{O}_{3}$ と近似し た $k_{1}$ 值を示し，Boudouard 反応の単一律速と見なされ るが, Sp 4 の $k_{1}$ はそれらの值よりかなり小さく CO 還元過程も還元速度に影響するものと思われる。

Sp 5 の $k_{1}$ は $1260^{\circ} \mathrm{C}$ において求めたものであるが, $1200^{\circ} \mathrm{C}$ の純 $\mathrm{Cr}_{2} \mathrm{O}_{3}$ および Sp 1 の $\mathrm{Cr}_{2} \mathrm{O}_{3}$ 成分の $k_{1}$ と比べてもはるかに小さく, CO 還元過程の単一律速と 見なすことがでさよう.なお，実測データはないが $\mathrm{Sp}$ 4 の $\mathrm{MgCr}_{2} \mathrm{O}_{4}$ 成分の還元段階においても同様の律速 機構が推測される.

炭材内装ペレットおよびท連鉱（-325 メッシュ）の $\mathrm{FeCr}_{2} \mathrm{O}_{4}$ 成分の還元段階の $k_{1}$ は, Sp 1 のコークスを 用いた場合の $k_{1}$ 見積值と比較してはるかに小さい。し たがつて鉱石の場合は $\mathrm{FeCr}_{2} \mathrm{O}_{4}$ 成分の還元段階におい ても CO 還元過程が主に律速すると推定される.

以上の検討結果を $\mathrm{FeCr}_{2} \mathrm{O}_{4}-\mathrm{MgCr}_{2} \mathrm{O}_{4}-\mathrm{MgAl}_{2} \mathrm{O}_{4} 3$ 元 組成図上にまとめると Fig. 13 のとおりである.な 拉，いずれの過程が律速するかは，クロマイトの組成の みならずクロマイトと炭材の相対的粒度差によつても変 化するので, 同図の結果は本研究で用いた粒度範囲の試 料に限つての律速過程と組成の関係を示すものである.

全般的に見ると, 組成が単純で, かつ $\mathrm{CO}$ 還元反応 の平衡 $P_{\mathrm{CO}_{2}} / P_{\mathrm{CO}}$ 比が比較的高いクロマイトの炭素還元 では Boudouard 反応が主に律速するのに反して, 組成 が複雑かつ平衡 $P_{\mathrm{CO}_{2}} / P_{\mathrm{CO}}$ 比が低い難還元性のクロマイ トの場合は $\mathrm{CO}$ 還元過程が主たる律速過程になる。ま た $\mathrm{Al}_{2} \mathrm{O}_{3}$ (したがつて $\mathrm{MgAl}_{2} \mathrm{O}_{4}$ ) をある濃度以上含む 


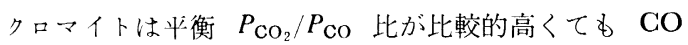
還元過程が律速しやすい。鉱石中のクロマイトは組成が 複雑で，例外なく $\mathrm{Al}_{2} \mathrm{O}_{3}$ をかなり高濃度に含むので, 微細試料を用いても $\mathrm{MgCr}_{2} \mathrm{O}_{4}$ 成分のみならず $\mathrm{FeCr}_{2} \mathrm{O}_{4}$ 成分の還元段階においても, CO 還元過程が主に律速す る.

\section{6. 結言}

$\mathrm{FeCr}_{2} \mathrm{O}_{4}$ の炭素還元速度データを $\mathrm{CO}-\mathrm{CO}_{2}$ 混合ガ スによる炭素の酸化速度式を適用して解析し, 反応ガス 王が低い場合は Boudouard 反応過程の単一律速と結論 した。しかし得られた反応速度定数は炭素単味の酸化速 度定数よりも同一温度, 同一炭種で比較して約 $10^{4}$ 倍大 きく，しかも活性化ェネルギーは 40〜 $45 \mathrm{kcal} / \mathrm{mol}$ とか なり低く，還元時に牛成する金属相および炭化物相が著 しい触媒作用を有することを示した。

$\mathrm{MgCr}_{2} \mathrm{O}_{4}$ の場合は Boudouard 反応の単一律速の条 件を見出せず，生成炭化物種の同定結果などから判断し て, Boudouard 反応と $\mathrm{CO}$ 還元反応の混合律速と推定 した.

さらに，組成の複雑な合成クロマイトおよびクロム鉱 石についても炭素還元における律速過程を検討した，組 成が単純で還元反応の平衡 $P_{\mathrm{CO}_{2}} / P_{\mathrm{CO}}$ 比が比較的高いク ロマイトの場合は Boudouard 反応が主に律速するが, 組成が複雑, かつ平衡 $P_{\mathrm{CO}_{2}} / P_{\mathrm{CO}}$ 比が低い難還元性のク ロマイト（とくに $\mathrm{Al}_{2} \mathrm{O}_{3}$ を含むクロマイト）の場合は $\mathrm{CO}$ 還元過程が律速することが解明された. 鉱石中のク ロマイトは組成が複雑で例外なく $\mathrm{Al}_{2} \mathrm{O}_{3}$ をかなり高濃 度に含むので, $\mathrm{MgCr}_{2} \mathrm{O}_{4}$ 成分のみならず $\mathrm{FeCr}_{2} \mathrm{O}_{4}$ 成 分の還元段階においても $\mathrm{CO}$ 還元過程が主に律速する.

おわりに, 本研究に対し種々有益な御助言をいただい た東北大学選鉱製錬研究所教授大谷正康博士ならびに室 蘭工大金属工学科教授田中章彦博士に感謝いたします。

\section{交献}

1) 片山 博, 田中章彦: 鉄と鋼, $60(1974), \mathrm{p}$. 1289

2) 片山 博：鉄と鋼，63 (1977), p. 207

3 ) 片山 博: 日本金属学会誌, 41 (1977), p. 275

4 ) 片山 博: 日本金属学会誌, 41 (1977), p. 427

5 ) 片山 博, 德田昌則: 鉄と鋼, 65 (1979), p. 331

6 ) $H . G$. Katayama and $M$. Tokuda: Trans.
ISIJ, 20 (1980), p. 154

7 ) 片山 博, 徳田昌則, 大谷正康：鉄之鋼, 70 (1984), p. 1559

8 ) W. J. Rankin: Trans. Inst. Min. Metall., 88 (1979), C 107

9 ) W. J. Rankin: Arch. Eisenhüttenwes., 50 (1979), S 373

10) $S . H$. Algie, $W . J$. Rankin and $C . W$. Finn: Trans. ISIJ, 24 (1984), p. 141

11）たと党ば，Y.K. RAO: J. Met. (1983) 7, p. 46

12）片山 博：日本金属学会誌，40 (1976), p. 993

13) P. V. Gel'd, V. G. Vlasov and $N . N$. Serebrenikov: Dokl. Akad. Nauk SSSR, 78 (1951), p. 693

14) P. V. Gel'd, $V . G$. Vlasov and $N . N$. Serebrenikov: Zhur. Priklad. Khim., 25 (1952), p. 121

15) A. A. Vertman and $A . M$. Samarin: Primenenie Vakuuma $v$ Met. Akad. Nauk SSSR, Inst. Met. im. A. A. Baikova, Trudy Soveshchan (1956), p. 132

16）小林三郎，大森康男：鉄と鋼，63 (1977), p. 1081

17) E. T. Turkdogan and $J . V$. Vinters: Carbon, 8 (1970), p. 39

18）片山 博：鉄之鋼，62 (1976)， S 416

19) H. K. KOHL and B. MARINCĚK: Arch. Eisenhüttenwes., 36 (1965), S 851

20) $H . K$. КоHL and B. MARINCĚK: Arch. Eisenhüttenwes., 38 (1967), S 493

21) $R$. Padilla and $H$. Y. Sohn: Metall. Trans., 10B (1979), p. 109

22) Y. K. RaO: Metall. Trans., 2 (1971), p. 1439

23) $M$. $C$. Aвraham and $A$. Ghosh: Ironmaking Steelmaking, 7 (1979), p. 14

24) R. J. Fruehan: Metall. Trans., 8B (1977), p. 279

25) $J . K$. Wright, $K . M c G$ Bowling and $A . L$. Morrison: Trans. ISIJ, 21 (1981), p. 149

26) $S$. $P$. Mehrotra and $V . K$. Sinha: Trans. ISIJ, 23 (1983), p. 723

27) $V$. Chandrasekhar, $A . A$. Vertman and $A$. $M$. SAMARin: Primenenie Vakuuma $\vee$ Met., A kad. Nauk SSSR, Inst. Met. Tr. Tretégo Soveshch. (1963), p. 179

28) $L . S$. Darken and E. T. Turkdogan: Heterogeneous Kinetics at Elevated Temperatures, ed. by $G$. $R$. Belton and $W$. L. Worrel (1970), p. 84 [Plenum Press]

29）片山 博，德田昌則：鉄と鋼，64 (1978), S 545

30) 片山博, 徳田昌則：鉄と鋼, 65 (1979), S 611

31) 片山 博, 徳田昌則, 大谷正康: 鉄と鋼, 67 (1981), S 665 